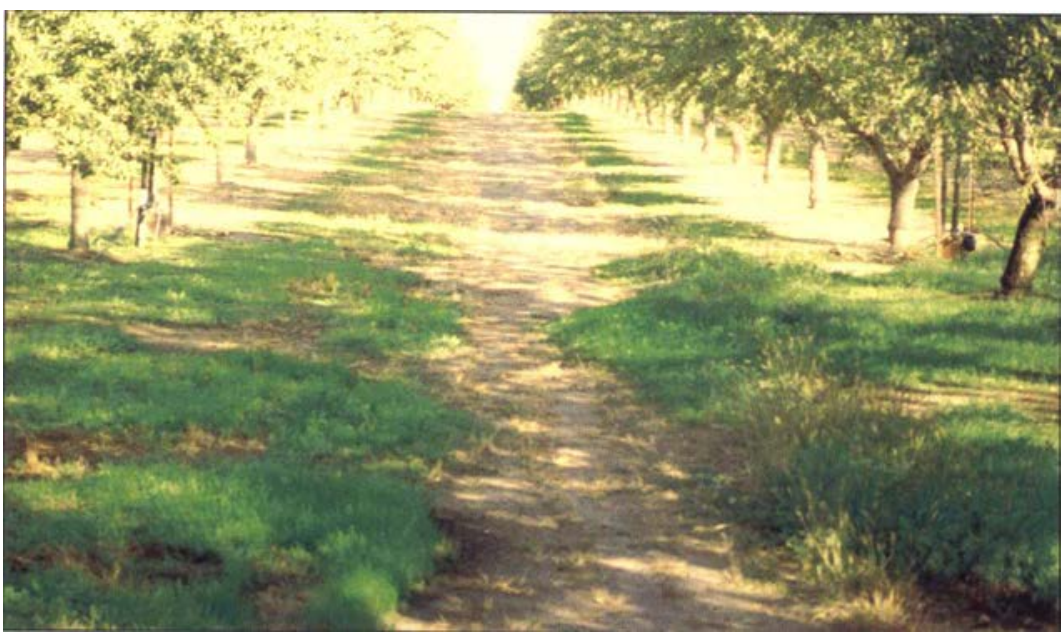

Summer weeds grow according to the wetting patterns of the microirrigation patterns. The microsprinklers in the foreground encourage more weeds than the subsurface drip in the back.

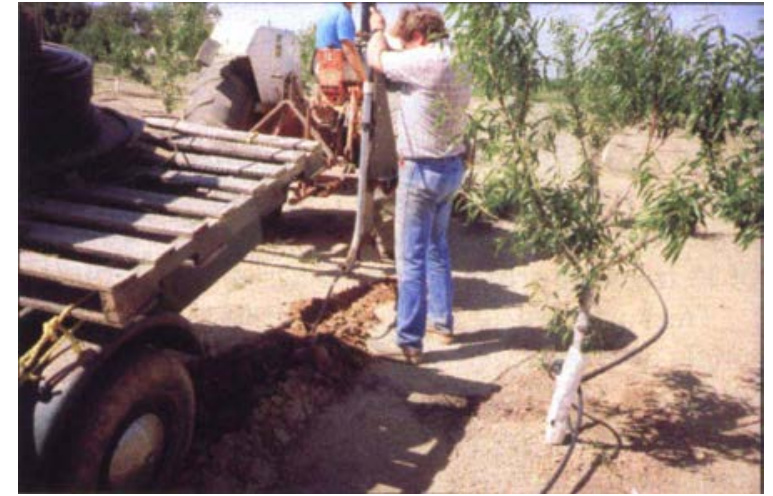

Two configurations of subsurface drip were installed 16 inches deep: a single lateral line, 2 feet from the tree row, and two lateral lines per tree row, each 4 feet from the trees.

\title{
Microsprinklers wet larger soil volume; boost almond yield, tree growth
}

\author{
Larry J. Schwankl $\square$ John P. Edstrom $\square \quad$ Jan W. Hopmans $\square$ Luis Andreu $\square \quad$ Kouman S. Koumanov
}

In the Arbuckle area of the Sacramento Valley, a 22-acre orchard was planted in 1990 with four almond varieties ('Nonpareil', 'Butte', 'Carmel' and 'Monterey'). The orchard was irrigated with three types of microirrigation surface drip, subsurface drip and microsprinklers. The orchard soils are 3 to 4 feet of gravelly, loamy sand overlaying a restricting clay layer. The coarse-textured soil with its low water-holding capacity allows little lateral movement of water from the microirrigation emission device. Under these soil conditions, microsprinklerirrigated trees produced larger almond yields and showed greater tree growth. In addition, irrigation system evaluations show that all three microirrigation systems provide excellent irrigation uniformity levels after 8 years of operation with only routine maintenance.
Interest in tree crop microirrigation systems (drip and microsprinkler irrigation) continues to increase in California. Although many factors affect a grower's decision to adopt microirrigation, two characteristics improved tree yield/crop quality and water application uniformity/efficiency improvements - play major roles.

The California almond industry has been progressive in its adoption of microirrigation. In the region where we conducted this study - the Sacramento Valley near Arbuckle - adoption of microirrigation has been especially widespread. In fact, irrigation systems other than microirrigation are unusual in new orchards in the

Arbuckle area.

The project was undertaken to collect additional information on the response of almonds irrigated with various types of microirrigation systems.

\section{Three types of microirrigation}

In 1990, a 22-acre planting of almonds was established at the Marine
Avenue section of the Nickel's Soils Laboratory near Arbuckle. The Nickel's Soils Laboratory is a trust, managed by UC, whose mission is to investigate soil, water and tree-crop issues of concern to orchardists in the Sacramento and northern San Joaquin valleys. It is typical of grower-owned orchards, with its revenue derived from the sale of its crops, predominantly almonds.

We designed the test orchard primarily to evaluate almond varieties and to compare their response to irrigation by various microirrigation systems. Four almond varieties ('Butte', 'Nonpareil', 'Carmel' and 'Monterey') were planted on 'Lovell' peach rootstock. All tree rows were 44 trees long, with a tree spacing of 16 feet by 22 feet. There were a total of 18 rows of 'Butte', 18 rows of 'Nonpareil', 9 rows of 'Carmel' and 9 rows of 'Monterey' almonds. The tree varieties were planted in a repeating row rotation of 'Butte', 'Nonpareil', 'Carmel', 'Butte', 'Nonpareil' and 'Monterey'. 
We installed three types of microirrigation systems - microsprinklers, surface drip irrigation and subsurface drip irrigation. The orchard was divided into 36 randomized plots, with 12 plots each of the 3 microirrigation systems. Each plot consisted of 6 rows of 11 trees (approximately 0.5 acres).

The surface drip treatments used a single drip lateral line per tree row, with four 1-gallon-per-hour (gph) pressure-compensating drippers per tree. The surface-drip-irrigation trees were established with two drippers per young tree. Two additional drippers were added at the beginning of the second year.

Two configurations of subsurface drip were installed: (1) a single lateral line, 2 feet from the tree row (4 plots), with 1-gph emitters spaced 4 feet apart; and (2) two lateral lines per tree row, each 4 feet from the tree row ( 8 plots), with 0.5 -gph emitters spaced 4 feet apart. All subsurface drip lines were shanked-in at a depth of 16 inches, and drip tubing with in-line or integrally constructed emitters was used. The application rates (inches/hr) of the subsurface drip systems were the same as those of the surface drip system. The subsurface-drip-irrigated trees were irrigated the first season using surface-drip irrigation only (two 1-gph emitters per tree), and the subsurface drip system was installed and used for irrigation beginning the second growing season.

The microsprinkler configuration selected was a single full-circle pattern microsprinkler placed midway between trees in the tree row. At the operating pressure of $18 \mathrm{psi}$, the microsprinklers discharged $10 \mathrm{gph}$, with a wetted diameter of approximately 14 feet. The microsprinklers therefore did not wet the crown of the tree. The microsprinkler-irrigated trees were established by placing a microsprinkler within a few feet of the young tree. The microsprinkler was modified with the addition of a "top hat" or other device that reduced the size of the wetted area. This ensured that the soil around the young tree received adequate water and reduced water losses outside the root zone.

Separate submains were installed for the drip (surface and subsurface) systems and for the microsprinklers. A key aspect of the microirrigation system comparison was that all trees would receive the same seasonal amount of irrigation water, regardless of irrigation method. The application rate of the microsprinklers (10 gph/tree) was substantially higher than that of the drip systems ( $4 \mathrm{gph}$ / tree), necessitating different irrigation schedules. Therefore separate submains were required.

The irrigation water for the Nickel's Soils Laboratory is supplied by the U.S. Bureau of Reclamation Central Valley Project via a local irrigation district. It is delivered to the orchard by pipeline, from which it is pressurized as needed. Standard sand media filtration was used at the pump head, with secondary screen filters placed in the orchard. Routine irrigation system maintenance included periodic chlorination and flushing on approximately a monthly basis during the growing season.

Irrigation amounts were determined through use of evapotranspiration (ET) estimates from a nearby California Irrigation Management Information System (CIMIS) station in Colusa. Before the orchard canopy reached full coverage, orchard water use was estimated by reducing full crop ET based on percentage of orchard cover (University of California 1989). ET estimates were confirmed using a variety of soil moisture monitoring devices, including tensiometers, gypsum blocks, a neutron probe and a time domain reflectometry (TDR) device. There was no summer cover crop in the orchard, and weeds were controlled by strip spraying the tree row with herbicides and mowing between tree rows. During midsummer (peak ET periods), the drip systems were operated daily and the microsprinklers were operated about once every 3 days.

\section{Irrigation system performance}

We have monitored irrigation system performance in the Marine Avenue orchard since its establishment. The irrigation systems were designed to be very uniform; all like emitters (drippers or microsprinklers) in the orchard discharge water at very nearly the same rate. The irrigation uniformity is quantified using emission uniformity (EU - \%) where:

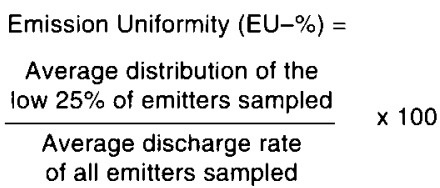

At an emission uniformity of $100 \%$, all emitters (for example, all drip emitters) discharge water at the same rate. An emission uniformity greater than $90 \%$ is considered excellent. From 1993 to 1995 , with support from the California Energy Commission, the discharge rates of over 500 drip emitters and nearly 600 microsprinklers were measured yearly to develop irrigation uniformity measures (table 1) (Schwankl et al. 1996). After 5 years of operation with only routine maintenance, the operation performance of the systems was excellent. Subsequent irrigation evaluations in 1996 and 1997 indicated that the emission uniformities remained excellent.

Irrigation evaluations on subsurface drip systems are extremely difficult. It is not feasible to excavate emitters for discharge measurement; therefore, we did not attempt to measure subsurface drip emission uniformity. As an alternative, small totalizing flow meters were permanently installed on selected subsurface drip laterals to monitor flow rate along the entire lateral length. Constant flow rate, at a constant operating pressure, indicates no significant clogging or leaking in the lateral line. In 1995, every subsurface drip lateral was monitored using portable flow meters because of concern about root intrusion. Using lateral line discharge measurements, excavations to inspect emitters, and observation of surface wetting, it was determined that root intrusion had not yet become a problem and that the subsurface drip lines were operating well.

It is desirable under subsurface drip irrigation to keep the orchard floor dry for weed control, orchard traffic and harvest considerations. Even though the subsurface drip lateral lines were 16 inches deep at the test orchard, water was still "surfacing" - wetting the soil surface above the emitters. This surfacing occurs as water rises 



Fig. 1. Soil moisture distribution around an almond tree for 3 days in 1995: Feb. 3, soil moisture profile refilled by winter rains; March 30 , soil moisture profile just before beginning irrigations; and July 28 , soil moisture profile typical of that under surface drip irrigation during the growing season.

through soil disturbed by shanking-in the drip tubing.

Evaporation from the wet soil surface occurs under all the microirrigation systems evaluated, but it is difficult to ascertain what portion of this evaporation is "lost" and what portion contributes to tree evapotranspiration. Evaporation under microsprinkler irrigation, particularly in a young orchard where the tree canopy is not fully developed, is probably greater compared to the drip and subsurface drip systems, due to both the larger wetted soil area and the spray losses during irrigation. A microsprinkler evaluation/soil moisture monitoring experiment was conducted as part of this trial (Koumanov et al. 1997), with the conclusion that there

TABLE 1. Irrigation emission uniformities for the surface drip and microsprinkler irrigation systems 1993-1995

\begin{tabular}{lccc}
\hline \hline & \multicolumn{3}{c}{ Emission uniformities } \\
\cline { 2 - 4 } Irrigation system & 1993 & 1994 & 1995 \\
\hline \multirow{2}{*}{ Surface drip } & $\ldots \ldots \ldots \ldots \ldots \ldots . .$. & $\% \ldots \ldots \ldots \ldots \ldots \ldots \ldots \ldots \ldots \ldots \ldots \ldots \ldots \ldots$ \\
Microsprinklers & 93 & 90 & 93 \\
\hline & 92 & 91 & 91 \\
\hline
\end{tabular}

were evaporative losses that could be reduced by irrigating during the night and morning hours. Because of their higher application rate designs, most microsprinkler systems can be operated to avoid the afternoon hours, when evaporative losses are highest. In addition, avoiding afternoon irrigation periods takes advantage of offpeak power rates, substantially reducing pumping costs.

\section{Almond tree performance}

To determine the response of the different almond varieties to the various microirrigation systems, both mean trunk diameter (measured at 1 foot above the ground surface) and almond yield were measured.

Mean trunk cross-sectional area. Mean trunk cross-sectional areas for 1994 through 1997 were compared by irrigation treatment for each of the almond varieties (table 2). The statistical comparison was done by almond variety for each year independently. Statistical significance was tested for a comparison between means at the $5 \%$ level. The microsprinkler-irrigated trees generally had a larger mean trunk crosssectional area than did the surface or subsurface drip-irrigated trees.

Almond nut yield. The statistical comparison of 1994 through 1997 yields was done by variety, with significance tested at the $5 \%$ level. No statistical comparison was done between varieties. Except for 1995, yields were generally higher for the microsprinkler-irrigated trees (table 3). 1995 was a difficult year for comparison because it was a poor almond season for much of California due to late winter rains during bloom. Because of variability between plot yields, the yield differences were not always statistically significant at the $5 \%$ level, but there was a definite trend toward increased yield with microsprinkler irrigation.

We have investigated a number of issues to explain the difference in yield between microirrigation methods. Since the amount of seasonal applied water was equal between all the microirrigation systems, the better microsprinkler-irrigated almond tree response is probably related to the wetted area of the microirrigation sys- 
tems and the soil conditions at the orchard. The soil in the orchard is an Arbuckle series and is characterized by 2 to 4 feet of gravelly, loamy sand overlaying a restricting clay layer. The gravel content of the upper layer is high, often greater than $20 \%$. Consequently, the soil is shallow, with a low water-holding capacity. In addition, because of its coarse texture, lateral water movement in the soil is limited.

Backhoe investigations at the end of the 1994 and 1995 seasons indicated a distinct difference in rooting patterns between the drip-irrigated and microsprinkler-irrigated trees. The drip irrigation systems wetted the soil within a zone 3 to 4 feet wide centered on the drip lateral line. The microsprinklers wetted a larger soil volume, slightly larger than the 14-foot throw diameter of the microsprinkler.

\section{Soil moisture distribution}

To further investigate the wetted volume of soil under surface drip irri-

\begin{tabular}{|c|c|c|c|c|}
\hline \multirow[b]{2}{*}{ Irrigation treatment } & \multicolumn{4}{|c|}{ Almond variety } \\
\hline & Carmel & Butte & Nonpareil & Monterey \\
\hline 1994 & \multicolumn{4}{|c|}{ 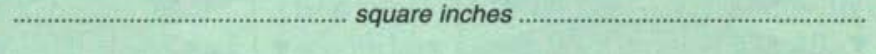 } \\
\hline Surface drip & $17.7 b^{*}$ & $22.2 \mathrm{~b}$ & $20.3 c$ & $21.2 \mathrm{a}$ \\
\hline Microsprinklers & $19.2 \mathrm{a}$ & $24.3 \mathrm{a}$ & $24.3 \mathrm{a}$ & $21.7 \mathrm{a}$ \\
\hline Subsurface drip & $17.1 \mathrm{~b}$ & $22.2 \mathrm{~b}$ & $21.3 b$ & $21.4 \mathrm{a}$ \\
\hline \multicolumn{5}{|l|}{1995} \\
\hline Surface drip & $23.0 \mathrm{~b}$ & $33.8 \mathrm{~b}$ & $29.8 \mathrm{~b}$ & $28.7 b$ \\
\hline Microsprinklers & $26.0 \mathrm{a}$ & $37.5 \mathrm{a}$ & $31.8 \mathrm{a}$ & $35.6 \mathrm{a}$ \\
\hline Subsurface drip & $24.4 b$ & $35.3 \mathrm{~b}$ & $29.8 \mathrm{~b}$ & $29.4 \mathrm{~b}$ \\
\hline \multicolumn{5}{|l|}{1996} \\
\hline Surface drip & $30.9 \mathrm{~b}$ & $44.6 \mathrm{~b}$ & $40.0 \mathrm{~b}$ & $36.2 \mathrm{~b}$ \\
\hline Microsprinklers & $35.6 \mathrm{a}$ & $52.9 \mathrm{a}$ & $43.4 \mathrm{a}$ & $48.9 \mathrm{a}$ \\
\hline Subsurface drip & $30.4 b$ & $46.7 b$ & $38.1 \mathrm{~b}$ & $36.7 b$ \\
\hline \multicolumn{5}{|l|}{1997} \\
\hline Surface drip & $35.9 \mathrm{a}$ & $52.0 \mathrm{~b}$ & $47.2 \mathrm{~b}$ & $41.6 \mathrm{~b}$ \\
\hline Microsprinklers & $38.2 \mathrm{a}$ & $55.9 \mathrm{a}$ & $49.7 \mathrm{a}$ & $53.4 \mathrm{a}$ \\
\hline Subsurface drip & $36.7 \mathrm{a}$ & $48.4 c$ & $45.8 \mathrm{~b}$ & $39.7 \mathrm{~b}$ \\
\hline \multicolumn{5}{|c|}{$\begin{array}{l}\text {-Statistical comparison of mean trunk diameters was done by variety and by year. Numbers followed by the same } \\
\text { letter are not significantly different at the } 5 \% \text { level. }\end{array}$} \\
\hline \multirow{2}{*}{\multicolumn{5}{|c|}{ Almond variety }} \\
\hline & & & & \\
\hline Irrigation treatment & Carmel & Butte & Nonpareil & Monterey \\
\hline 1994 & & & ............... & \\
\hline Surface drip & & $1,047 b^{*}$ & $1,053 \mathrm{c}$ & \\
\hline Microsprinklers & & $1,543 a$ & $1,532 \mathrm{a}$ & \\
\hline Subsurface drip & & $1,235 b$ & $1,234 b$ & \\
\hline \multicolumn{5}{|l|}{1995} \\
\hline Surface drip & $752 a$ & $745 a$ & $920 \mathrm{a}$ & $1,293 \mathrm{a}$ \\
\hline Microsprinklers & $715 \mathrm{a}$ & $726 \mathrm{a}$ & $983 \mathrm{a}$ & $1,332 \mathrm{a}$ \\
\hline Subsurface drip & $873 a$ & $701 \mathrm{a}$ & $639 \mathrm{~b}$ & $1,241 \mathrm{a}$ \\
\hline \multicolumn{5}{|l|}{1996} \\
\hline Surface drip & $1,777 \mathrm{a}$ & $1,924 \mathrm{a}$ & $2,362 \mathrm{a}$ & $2,492 a b$ \\
\hline Microsprinklers & $1,748 \mathrm{a}$ & $2,276 b$ & $2,708 \mathrm{a}$ & $2,884 a$ \\
\hline Subsurface drip & $1,673 \mathrm{a}$ & $1,845 \mathrm{a}$ & $2,350 \mathrm{a}$ & $2,231 \mathrm{ab}$ \\
\hline \multicolumn{5}{|l|}{1997} \\
\hline Surface drip & $2,002 \mathrm{a}$ & 2,468 a & $1,991 \mathrm{a}$ & $1,948 a b$ \\
\hline Microsprinklers & $1,888 \mathrm{a}$ & $2,513 a$ & $2,179 a$ & $2,252 \mathrm{a}$ \\
\hline Subsurface drip & $1,829 \mathrm{a}$ & $2,422 \mathrm{a}$ & $1,846 \mathrm{a}$ & $1,714 \mathrm{~b}$ \\
\hline \multicolumn{5}{|c|}{ Combined Average 1996-97 } \\
\hline Surface drip & $1,900 \mathrm{a}$ & $2,217 \mathrm{a}$ & $2,176 a$ & $2,220 a b$ \\
\hline Microsprinklers & $1,832 \mathrm{a}$ & $2,394 \mathrm{a}$ & $2,444 \mathrm{a}$ & $2,568 \mathrm{a}$ \\
\hline Subsurface drip & $1,746 \mathrm{a}$ & $2,133 \mathrm{a}$ & $2,085 a$ & 1,972 b \\
\hline
\end{tabular}

- Statistical comparison of yield was done by variety and by year. Numbers followed by the same letter are not significantly different at the $5 \%$ level. 


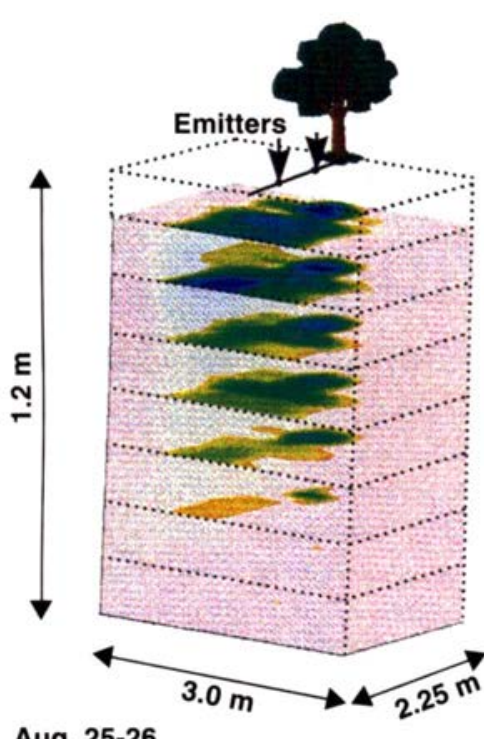

Aug. 25-26



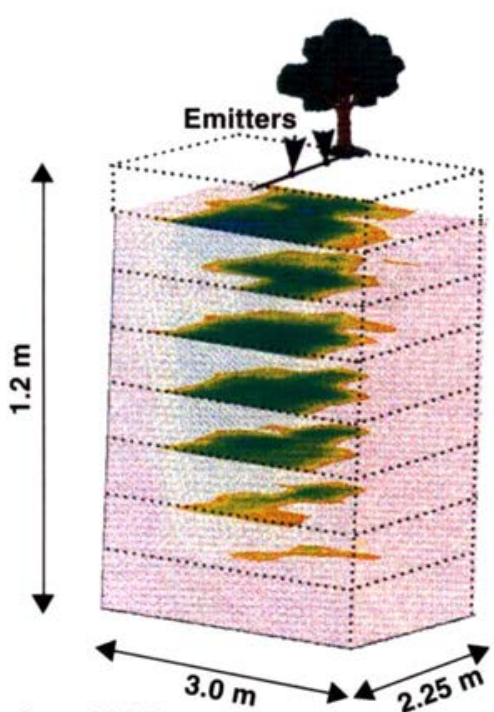

Aug. 26-27

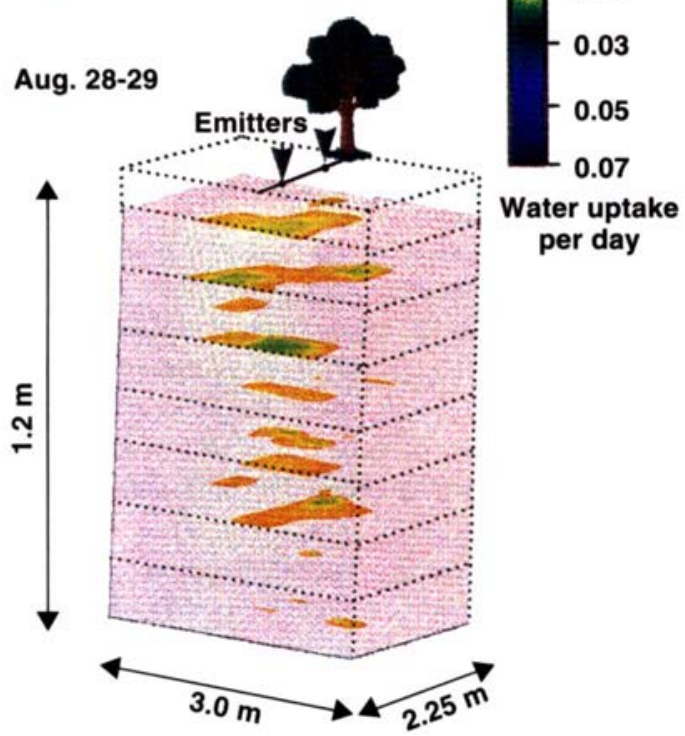

Fig. 2. Water uptake for 4 days in 1995 following a drip irrigation. Aug. 25-26 (day 1 ) shows water uptake primarily from the zones close to the tree. Aug. 26-27 (day 2) indicates water uptake moving to zones farther from the tree as the closer zones become depleted. Aug. 27-28 (day 3 ) indicates decreased water uptake throughout the profile, but occurring at deeper depths and farther from the tree. Aug. 28-29 (day 4) shows significantly decreased water uptake around the tree as soil moisture is depleted throughout most of the soil profile.

Harvest, which occurs in late August and September, is a time when tree water demands can still be quite high, but irrigation and harvest activities may conflict with each other. Experience has shown that irrigations need to be applied in this orchard during harvest to minimize tree water stress and defoliation. Irrigation while almonds are on the ground and before nut pickup was easier with the drip systems - both surface and subsurface drip - than with the microsprinkler systems. Microsprinklers needed to be operated at much reduced pressure to limit the wetted diameter and keep the nuts dry.

Under the soil conditions at Marine Avenue, shallow soils with a low water-holding capacity and little lateral wetting capability, there appears to be an advantage to wetting a larger volume of soil, as with microsprinklers. Under more favorable soil conditions, where soils are deeper, hold more available water, and promote more lateral wetting, this advantage may not occur. If surface drip irrigation were to be used under soil conditions similar to those of the test orchard, it could be advantageous to use a double lateral line drip system (a lateral on either side of the tree row) to wet a larger soil volume.

\section{Microsprinklers show advantage}

Results from multiple years of monitoring an almond orchard, planted in a shallow, low-waterholding-capacity soil with little lateral wetting capability, and irrigated with various microirrigation systems, showed an advantage to irrigating with microsprinklers. For the four almond varieties investigated ('Butte', 'Nonpareil', 'Monterey' and 'Carmel'), both mean trunk diameter and almond yield were generally greater when irrigated with microsprinklers as compared to those irrigated with surface drip or subsurface drip.

With only routine maintenance, irrigation system performance for all three microirrigation systems, measured by emission uniformity, has remained excellent for the 8 years since installation.

L. Schwankl is UCCE Irrigation Specialist and J. Hopmans is Professor, Department of Land, Air, and Water Resources, Hydrologic Sciences, UC Davis; J. Edstrom is Pomology Farm Advisor, UCCE Colusa County; L. Andreu is Water Management Researcher located at the University of Seville, Spain; and K.S. Koumanov is Water Management Researcher at the Fruit Growing Institute, Plovdiv, Bulgaria.

Support for this work was provided by the California Energy Commission and by BARD (U.S.-Israel Binational Agricultural Research and Development Fund). The authors extend their appreciation to Stan Cutter, field manager at the Nickel's Laboratory, for his excellent support and cooperation.

\section{References}

Andreu L, Hopmans JW, SchwankI LJ. 1997. Spatial and temporal distribution of soil water balance for a drip-irrigated almond tree. Agric Water Management 35:123-46.

Koumanov KS, Hopmans JW, Schwankl LJ et al. 1997. Application efficiency of microsprinkler irrigation of almond trees. Agric Water Management 34:247-63.

Schwankl LJ, Edstrom JP, Hopmans JW. 1996. Performance of microirrigation systems in almonds. Proceedings of 7 th International Conference on Water and Irrigation. Tel Aviv, Israel.

University of California, Division of Agriculture and Natural Resources. 1989. Using Reference Evapotranspiration (Eto) and Crop Coefficients to Estimate Crop Evapotranspiration (Etc) for Trees and Vines. Leaflet 21428. 